\title{
Influence of Beet necrotic yellow vein virus on Sugar Beet Storability
}

Carl A. Strausbaugh, United States Department of Agriculture-Agricultural Research Service NWISRL, Kimberly, ID 83341; Eugene Rearick, Amalgamated Research, Inc., Twin Falls, ID 83301; Stacey Camp, Amalgamated Sugar Co., Paul, ID 83347; John J. Gallian, University of Idaho, Research and Extension Center, Twin Falls 83303; and Alan T. Dyer, Montana State University, Bozeman 59717

\begin{abstract}
Strausbaugh, C. A., Rearick, E., Camp, S., Gallian, J. J., and Dyer, A. T. 2008. Influence of Beet necrotic yellow vein virus on sugar beet storability. Plant Dis. 92:581-587.

Rhizomania caused by Beet necrotic yellow vein virus (BNYVV) and storage losses are serious sugar beet production problems. To investigate the influence of BNYVV on storability, six sugar beet cultivars varying for resistance to BNYVV were grown in 2005 and 2006 in southern Idaho fields with and without BNYVV-infested soil. At harvest, samples from each cultivar were placed in an outdoor ventilated pile in Twin Falls, ID and were removed at 40-day intervals starting at the end of October. After 144 and 142 days in storage, sugar reduction across cultivars averaged 20 and 13\% without and 68 and $21 \%$ with BNYVV for the 2005 and 2006 roots, respectively. In the December samplings, frozen root area was 1 and $2 \%$ without and 25 and $41 \%$ with BNYVV for the 2005 and 2006 roots, respectively. Root rot was always worse with stored roots from BYNVV-infested soil in December, January, and February samplings. Root weight loss was variable in 2005; however, in 2006, an increase in weight reduction always was associated with BNYVV-infested roots. In order to prevent losses in rhizomania-infested areas, cultivars should be selected for storability as well as rhizomania resistance.
\end{abstract}

Preventing sucrose losses in long-term storage is critical to the viability of the sugar beet industry. Loss of sucrose beyond normal respiration can be attributed to the physiological state of the root, dehydration, microbial activity, harvest conditions (mud, frost, high temperatures, and so on), and injuries from harvest and cleaning operations $(4,5,9-13,26)$.

In the pile, storage fungi reduce recoverable sucrose levels of stored beet. The major causes of storage decay have been identified as Phoma betae A. B. Frank, Penicillium claviforme Bainier, Botrytis cinerea Pers., and Fusarium spp. (4). For instance, it has been reported that the respiration rate of stored sugar beet roots will double when approximately $20 \%$ of their surface area is infected by Penicillium and Botrytis spp. (15). These infections also lead to a threefold increase in reducing sugars, which are problematic to sucrose extraction (15). Recently, the influence of fungal infections in the field on storability of sugar beet was investigated in Germany under controlled storage conditions. Storability was found to be impaired by

Corresponding author: C. A. Strausbaugh

E-mail: carl.strausbaugh@ars.usda.gov

Accepted for publication 7 November 2007.

doi:10.1094/PDIS-92-4-0581

This article is in the public domain and not copyrightable. It may be freely reprinted with customary crediting of the source. The American Phytopathological Society, 2008.
Rhizoctonia solani J.G. Kühn but not by Cercospora beticola Sacc. (12).

In southern Idaho, much of the sugar beet crop is stored from mid-October to mid-March in piles $6.1 \mathrm{~m}$ high by $36.6 \mathrm{~m}$ wide at the base (24.4 m wide at top) (17). In southern Idaho, approximately one-third of the sugar beet roots are directly processed, one-third are held in short-term storage, and one-third are held in longterm (>90 days) storage (17). For 2006, one-third of the sugar beet roots for southern Idaho would have been approximately 1.7 million metric tons (16). The factory processing campaign begins in late September with roots directly from the field but eventually shifts to using only stored roots sometime in November. The extractability of sugar from stored beet will vary depending on impurities such as potassium, sodium, amino-N, invert sugars, and substances associated with rot organisms such as dextran (5). Maintaining sucrose concentration and root quality during storage is important for maintaining factory efficiency.

Rhizomania, caused by Beet necrotic yellow vein virus (BNYVV), has become one of the most serious diseases of sugar beet worldwide $(14,18,19,22)$. The primary means of controlling this disease is through host resistance based largely on the Rzl gene $(18,19)$. However, strains of BNYVV that overcome the $R z l$ gene have been documented (14). Concerns also have been raised that BNYVV may influence the storability of sugar beet. A preliminary report suggesting that disease agents may compromise storability of sugar beet prompted this investigation on the influence of BNYVV on the storability of sugar beet (21).

\section{MATERIALS AND METHODS}

Treatments. The study examined 12 treatments, consisting of six commercial sugar beet cultivars from fields with and without rhizomania-infested soil from the 2005 growing season, and was repeated with roots from the 2006 season. One of the six cultivars, HM Owyhee, was susceptible to rhizomania and is among the best commercial cultivars for resistance to curly top. The other five cultivars contained resistance genes to rhizomania and also were selected for their performance against curly top. Rhizomania was uniform and evident throughout the infested field in both years. Curly top, caused by Beet severe curly top virus and closely related species, also was present at moderate levels in the 2005 fields but only at trace levels in the 2006 fields. The influence of curly top was ameliorated by host resistance and the use of the insecticide Temik 15G (15\% aldicarb). Powdery mildew, caused by Erysiphe polygoni DC., also was present in the 2005 infested field; however, the most susceptible cultivars (Beta 4490 $\mathrm{R}$ and Beta $4199 \mathrm{R}$ ) had the least sucrose loss in the storage work. Thus, powdery mildew should have had very little influence on the storage work. Root rots and other fungal and bacterial diseases were not evident in the fields and the roots were free of visible root rot at harvest. At both the disease-free and rhizomania fields, the six cultivars were arranged in a randomized complete block design with four replications as four-row plots, $10.4 \mathrm{~m}$ long, with rows $0.6 \mathrm{~m}$ apart. The fields were managed using standard commercial cultural practices. At harvest, six eight-beet samples were collected in nylon mesh onion bags from each plot. Two of the samples were submitted to the Amalgamated Tare Lab for sugar analysis. The storage samples were piled inside a metal corrugated ventilation pipe $(0.9 \mathrm{~m}$ in diameter) on top of plywood in the same experimental design and blocks as arranged in the field. The samples inside the pipe covered an area of $6.1 \mathrm{~m}$, with the initial $6.1 \mathrm{~m}$ of the open end of the pipe unused. The open end of the pipe was covered with straw bales. The pipe was lo- 
cated on top of a 30-cm layer of beet. The pipe was covered by roots piled to a height of $6.1 \mathrm{~m}$. The pile was ventilated using the same perforated pipe placed $3.7 \mathrm{~m}$ on center. The storage pipe with the samples was placed between the two ventilation pipes. The roots surrounding the pipe were from commercial cultivars and healthy in appearance (no visible rhizomania or rot symptoms). The samples were retrieved at 40-day intervals beginning on 31 October 2005 and 1 November 2006. Temperature inside the storage tube was recorded on a Hobo temperature sensor (Onset Computer Corp., Bourne, MA) at 1-h intervals. Cv. HM 2980 RZ was not available in 2006; thus, we included HM 2984 RZ in place of this cultivar.

2005 Rhizomania field samples. The field was located on a research farm at the College of Southern Idaho in Twin Falls. Barley had been grown on the field the previous year. Sugar beet was planted on 3 May 2005. The insecticide Temik 15G was applied at $22.4 \mathrm{~kg} / \mathrm{h}$ during bedding on 19 April 2005. The field was mechanically topped and harvested on 5-6 October with a small-plot harvester. Storage samples were held outdoors in a shaded area until they were placed inside the pipe in the Twin Falls ventilated pile on 17 October.

2005 Field samples disease-free in appearance. The plots were within a commercial field $14.5 \mathrm{~km}$ north of Rupert, ID. The field had been in potato in 2004 and was planted to sugar beet on 5 April 2005. The insecticide Temik $15 \mathrm{G}$ at $15.7 \mathrm{~kg} / \mathrm{h}$ was applied during cultivation on 28 May 2005. The plants were hand topped and harvested on 7 October. The storage samples were held outdoors in a shaded area until they were placed inside the Twin Falls ventilated pile on 17 October.

2006 Rhizomania field samples. The trial was located in a commercial field 11.3 $\mathrm{km}$ north of Rupert, ID. The field had been in spring barley in 2005 and was planted to sugar beet on 10 April 2006. The insecticide Temik $15 \mathrm{G}$ was applied at $16.8 \mathrm{~kg} / \mathrm{h}$ on 20 June 2006. The plants were hand topped and harvested on 6 October. The storage samples were held outdoors in a shaded area until they were placed inside the Twin Falls ventilated pile on 19 October.

2006 Field samples disease-free in appearance. The plots were within a commercial grower's field located $6.4 \mathrm{~km}$ south of Nampa, ID. The field had been in
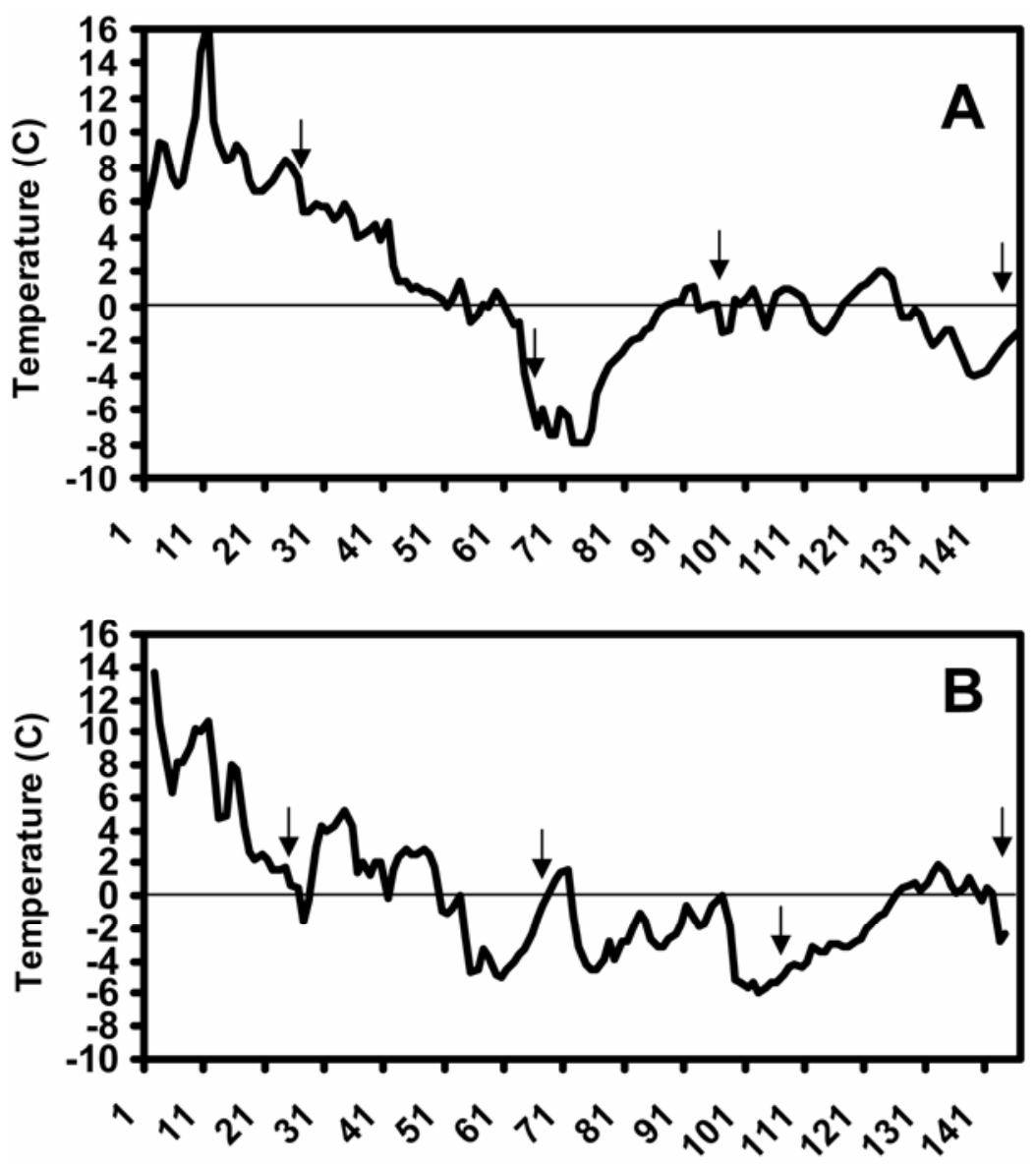

\section{Days In storage}

Fig. 1. Average daily temperature $\left({ }^{\circ} \mathrm{C}\right)$ during storage A, from 5 October 2005 to 28 February 2006 and B, from 6 October 2006 to 26 February 2007 in an outdoor commercial sugar beet pile in Twin Falls, ID. Arrows designate when storage samples were retrieved.

corn in 2005 and was planted to sugar beet on 27 March 2006. The insecticide Temik $15 \mathrm{G}$ was applied at $16.8 \mathrm{~kg} / \mathrm{h}$ on 15 May 2006. The plants were hand topped and harvested on 12 October. Storage samples were held outdoors in a shaded area until they were placed inside the Twin Falls ventilated pile on 19 October.

Rhizomania, rot, and freeze damage ratings. After being retrieved from the storage pile on each sampling date, the roots were evaluated for rhizomania symptoms using a 0 -to-9 disease index, where 0 $=$ no symptoms; 1 = root growth normal, minor bearding, and no discoloration; $2=$ taproot slightly constricted and bearded; 3 $=$ taproot moderately constricted, bearded, and discolored with very little adhering soil; $4=$ similar to 3 except more adhering soil; 5 = taproot wine-glass shaped, discolored, and brittle and feeder roots bearded with soil adhering; $6=$ damage to taproot severe and probably nonfunctional, with severe bearding just below the crown; 7 = taproot destroyed and severe bearding below the crown, with root area a ball of soil; $8=$ similar to 7 except root necrotic into the crown area; $9=$ root dead. The index is similar to one published previously (23) and was utilized in a continuous manner rather than categorically. At the same time, surface rot also was evaluated as the percentage of root area associated with rot damage such as dry black rot, wet bacterial rot, or tissue covered with fungal growth. The percentage of root area associated with freeze damage (frost on root surface, tissue translucent, and so on) also was established at the time of retrieval from storage. No freeze data were obtained on the first sampling date because no freezing had occurred. No attempt was made to analyze the roots for frozen root area in the February samplings, because the roots had deteriorated too badly from rot.

Weight analysis. Prior to placing the storage samples in the pile, each sample was weighed. The samples were reweighed when retrieved from the storage pile. These weights were used to determine reduction in root weight.

Sugar analysis. Two of the six samples collected from each plot were submitted to the Amalgamated Tare Lab in Paul, ID at the time of harvest. Percent sugar was determined using an Autopol 880 polarimeter (Rudolph Research Analytical, Hackettstown, NJ) and a half-normal weight sample dilution and aluminum sulfate clarification method (ICUMSA Method GS6-3 1994; 2). Percent sugar for samples coming out of storage was determined by Amalgamated Research Inc. in Twin Falls, ID using gas chromatography, because polarimeter readings can be affected by impurities that accumulate during storage. The gas chromatographic method was similar to ICUMSA Method GS4/7/8/5-2 (2002) with the following 
modifications: the internal standard used was D(-)-salicin (2-[hydroxymethyl]phenyl$\beta$-D-glucopyranoside) and equal volumes (to $\pm 0.01 \mathrm{ml}$ ) of a solution of internal standard in dimethylformamide were dispensed into weighed samples and standards using a volumetric dispenser (2). To compare the two sugar analysis techniques, 16-beet samples were pulled from 24 different plots. The samples were split and then analyzed with the polarimeter and gas chromatograph. The gas chromatography analysis averaged $1.395 \%$ higher. To establish percent reduction in sugar at harvest versus storage, only samples from within the same plot were compared. Percent sugar reduction was established using the following equation: percent reduction in pounds of sugar $=\left(1-\left\{\left[(\%)\right.\right.\right.$ sugar $_{\text {storage }}$ sample -1.395$) \times$ weight $\left._{\text {storage sample }}\right] /(\%$ sugar $_{\text {harvest sample }} \times$ weight $\left.\left.\left._{\text {harvest sample }}\right)\right\}\right) \times$ 100.

Data analysis. Data were analyzed in SAS (20) using the general linear models procedure (Proc GLM), and Fisher's protected least significant difference was used for mean comparisons. Single degree-offreedom contrasts also were conducted. Bartlett's Test was used to establish homogeneity of variance.

\section{RESULTS}

Temperature. During the 2005-06 storage season, there was a cold period that began on 8 December 2005 (Fig. 1). The average daily temperature in the pipe ranged between -6 and $-8^{\circ} \mathrm{C}$ for 10 consecutive days. Temperatures then moderated and the average temperature remained above $0^{\circ} \mathrm{C}$ for 25 days between 1 January 2006 and 6 February 2006. During the 2006-07 storage season, temperatures in the pipe dropped below $0^{\circ} \mathrm{C}$ on $26 \mathrm{No}-$ vember 2006 and stayed below zero for 71 of the next 76 days (Fig. 1). The lowest average daily temperature during this period was $-5.9^{\circ} \mathrm{C}$.

Rhizomania ratings. Rhizomania rating data for 2005 differed between sampling dates $(P<0.0001)$. Rhizomania rating data for 2006 did not differ between sampling dates $(P=0.2157)$ and variances were homogeneous $(P=0.8837)$. In 2005 and 2006, all six cultivars from the rhizomaniainfested field had significantly higher rhizomania root ratings than the same six cultivars from a field lacking foliar and root symptoms of rhizomania (Table 1). The rhizomania-susceptible check, HM Owyhee, had the highest rhizomania ratings in the infested fields both years. Single degree-of-freedom contrast also showed that cultivars from the infested field (mean rating of 2.6) had more rhizomania root symptoms $(P<0.0001)$ than those from the noninfested field (mean rating of 0.0 ).

Surface rot. Surface rot data were analyzed separately for the two storage seasons because experiments were different on all four sampling dates $(P=0.0026$, $0.0009,0.0033$, and 0.0001 , respectively). On the 31 October 2005 sampling, five of the cultivars from the rhizomania-infested field had more root rot than those from the noninfested field (Table 2). In the 1 November 2006 sampling, no root rot was evident (Table 3). In the 9 December 2005 sampling, all cultivars from the infested field had more root rot (19 to $25 \%$ ) than those from the noninfested field (2 to 6\%). In the 12 December 2006 sampling, HM Owyhee and HM 2984 from the infested field had more root rot than from the noninfested field, whereas the other cultivars did not differ. In the 18 January 2006 sampling, all cultivars from the infested field
(51 to $70 \%$ ) had considerably more root rot than those from the noninfested field (4 to $14 \%$ ). In the 22 January 2007 sampling, only HH Meridian R had more rot from the infested field than from the noninfested field. In the 28 February 2006 sampling, root appearance of the cultivars from the infested field was poor ( 72 to $88 \%$ ). Cultivars from the noninfested field also had rot ( 25 to $42 \%$ ) but it not as severe as in those from the infested field. In the 26 February 2007 sampling, there was more root rot on five of the six cultivars from the infested field (25 to $40 \%$ ) than on the previous sampling date, whereas those from the noninfested field still had very little root rot (7 to 14\%). Comparisons across culti-

Table 1. Severity of rhizomania symptoms for sugar beet roots harvested from disease-free and rhizomania-infested trials

\begin{tabular}{|c|c|c|c|c|c|c|}
\hline \multirow[b]{3}{*}{ Cultivar } & \multirow[b]{3}{*}{$\operatorname{Virus}^{x}$} & \multicolumn{5}{|c|}{ Rhizomania visual root ratingw } \\
\hline & & \multicolumn{4}{|c|}{2005 roots } & \multirow[b]{2}{*}{2006 roots } \\
\hline & & 31 Oct 05 & 9 Dec 05 & 18 Jan 06 & 28 Feb 06 & \\
\hline HM Owyhee & BNYVV & $3.2 \mathrm{a}$ & $4.2 \mathrm{a}$ & $5.0 \mathrm{a}$ & $4.2 \mathrm{a}$ & $4.8 \mathrm{a}$ \\
\hline HM $2980 \mathrm{RZ}^{\mathrm{y}}$ & BNYVV & $1.2 \mathrm{c}$ & $3.4 \mathrm{~b}$ & $3.4 \mathrm{~b}$ & $2.2 \mathrm{~b}$ & $2.7 \mathrm{~b}$ \\
\hline Beta $4490 \mathrm{R}$ & BNYVV & $1.9 \mathrm{~b}$ & $2.9 \mathrm{~b}$ & $3.1 \mathrm{~b}$ & $1.8 \mathrm{bc}$ & $2.4 \mathrm{c}$ \\
\hline Beta $4199 \mathrm{R}$ & BNYVV & $1.4 \mathrm{bc}$ & $3.0 \mathrm{~b}$ & $3.0 \mathrm{~b}$ & $2.0 \mathrm{bc}$ & $2.3 \mathrm{c}$ \\
\hline HH Acclaim R & BNYVV & $1.2 \mathrm{c}$ & $1.9 \mathrm{c}$ & $2.0 \mathrm{c}$ & $1.9 \mathrm{bc}$ & $1.7 \mathrm{~d}$ \\
\hline HH Meridian R & BNYVV & $1.2 \mathrm{c}$ & $2.9 \mathrm{~b}$ & $3.1 \mathrm{~b}$ & $1.6 \mathrm{c}$ & $1.5 \mathrm{~d}$ \\
\hline HM Owyhee & None & $0.0 \mathrm{~d}$ & $0.0 \mathrm{~d}$ & $0.0 \mathrm{~d}$ & $0.0 \mathrm{~d}$ & $0.0 \mathrm{e}$ \\
\hline HM 2980 RZ & None & $0.0 \mathrm{~d}$ & $0.0 \mathrm{~d}$ & $0.0 \mathrm{~d}$ & $0.0 \mathrm{~d}$ & $0.0 \mathrm{e}$ \\
\hline Beta $4490 \mathrm{R}$ & None & $0.0 \mathrm{~d}$ & $0.0 \mathrm{~d}$ & $0.0 \mathrm{~d}$ & $0.0 \mathrm{~d}$ & $0.0 \mathrm{e}$ \\
\hline Beta $4199 \mathrm{R}$ & None & $0.0 \mathrm{~d}$ & $0.0 \mathrm{~d}$ & $0.0 \mathrm{~d}$ & $0.0 \mathrm{~d}$ & $0.0 \mathrm{e}$ \\
\hline HH Meridian R & None & $0.0 \mathrm{~d}$ & $0.0 \mathrm{~d}$ & $0.0 \mathrm{~d}$ & $0.0 \mathrm{~d}$ & $0.0 \mathrm{e}$ \\
\hline HH Acclaim R & None & $0.0 \mathrm{~d}$ & $0.0 \mathrm{~d}$ & $0.0 \mathrm{~d}$ & $0.0 \mathrm{~d}$ & $0.0 \mathrm{e}$ \\
\hline$P>F^{\mathrm{z}}$ & $\ldots$ & $<0.0001$ & $<0.0001$ & $<0.0001$ & $<0.0001$ & $<0.0001$ \\
\hline $\operatorname{LSD}(P \leq 0.05)$ & $\ldots$ & 0.5 & 0.5 & 0.5 & 0.5 & 0.2 \\
\hline
\end{tabular}

${ }^{\mathrm{w}}$ Rhizomania visual root rating based on a scale of 0 to $9(0=$ healthy and $9=$ dead $)$ determined when retrieved from storage. Sugar beet roots were harvested and put into storage between 5 and 12 October. Data from 2005 sampling dates were not analyzed together because they differed $(P<0.0001)$. Data from 2006 sampling dates were analyzed together because they did not differ $(P=0.2157)$ and variances were homogeneous $(P=0.8837)$.

${ }^{\mathrm{x}} \mathrm{BNYVV}=$ Beet necrotic yellow vein virus

y Cv. HM 2980 RZ was not available in 2006; therefore, cv. HM 2984 RZ was used instead.

${ }^{\mathrm{z}} P>F$ was the probability associated with the $F$ value. LSD $=$ Fisher's protected least significant difference value.

Table 2. Percentage of root surface exhibiting rot on sugar beet roots harvested in October 2005 from disease-free and rhizomania-infested trials after storage in an outdoor commercial pile in Twin Falls, ID

\begin{tabular}{llcccc}
\hline & & \multicolumn{4}{c}{ Surface rot $(\%)^{\mathbf{x}}$} \\
\cline { 3 - 6 } Cultivar & Virus $^{\mathbf{y}}$ & $\mathbf{3 1 ~ O c t ~ 2 0 0 5}$ & $\mathbf{9}$ Dec 2005 & $\mathbf{1 8 ~ J a n ~ 2 0 0 6}$ & 28 Feb 2006 \\
\hline HM Owyhee & BNYVV & $24 \mathrm{a}$ & $25 \mathrm{a}$ & $66 \mathrm{ab}$ & $88 \mathrm{a}$ \\
HH Acclaim R & BNYVV & $10 \mathrm{~b}$ & $21 \mathrm{ab}$ & $62 \mathrm{abc}$ & $86 \mathrm{a}$ \\
HH Meridian R & BNYVV & $10 \mathrm{~b}$ & $23 \mathrm{ab}$ & $70 \mathrm{a}$ & $85 \mathrm{a}$ \\
HM 2980 RZ & BNYVV & $4 \mathrm{~cd}$ & $19 \mathrm{~b}$ & $54 \mathrm{~cd}$ & $82 \mathrm{ab}$ \\
Beta 4199 R & BNYVV & $11 \mathrm{~b}$ & $19 \mathrm{~b}$ & $51 \mathrm{~d}$ & $75 \mathrm{bc}$ \\
Beta 4490 R & BNYVV & $9 \mathrm{bc}$ & $24 \mathrm{ab}$ & $59 \mathrm{bcd}$ & $72 \mathrm{c}$ \\
HH Acclaim R & None & $0 \mathrm{~d}$ & $6 \mathrm{c}$ & $9 \mathrm{ef}$ & $42 \mathrm{~d}$ \\
HH Meridian R & None & $1 \mathrm{~d}$ & $4 \mathrm{c}$ & $13 \mathrm{ef}$ & $42 \mathrm{~d}$ \\
Beta 4490 R & None & $0 \mathrm{~d}$ & $2 \mathrm{c}$ & $5 \mathrm{ef}$ & $41 \mathrm{~d}$ \\
Beta 4199 R & None & $0 \mathrm{~d}$ & $2 \mathrm{c}$ & $4 \mathrm{f}$ & $38 \mathrm{de}$ \\
HM 2980 RZ & None & $1 \mathrm{~d}$ & $2 \mathrm{c}$ & $6 \mathrm{ef}$ & $30 \mathrm{ef}$ \\
HM Owyhee & None & $2 \mathrm{~d}$ & $2 \mathrm{c}$ & $14 \mathrm{e}$ & $25 \mathrm{f}$ \\
$P>F^{z}$ & $\ldots$ & $<0.0001$ & $<0.0001$ & $<0.0001$ & $<0.0001$ \\
LSD $(P \leq 0.05)$ & $\ldots$ & 6 & 6 & 9 & 9
\end{tabular}

x Surface rot $=$ percentage of root area covered with fungal growth or rotted tissue. Sugar beet were harvested 5 to 7 October 2005.

${ }^{\mathrm{y}} \mathrm{BNYVV}=$ Beet necrotic yellow vein virus .

${ }^{\mathrm{z}} P>F$ was the probability associated with the $F$ value. LSD $=$ Fisher's protected least significant difference value. 
vars based on contrasts show that surface root rot was greater $(P<0.0001)$ in roots from the infested fields on all sampling dates both years, except for the 1 November 2006 sampling. A diversity of fungi were isolated from the rotted tissue (data not shown) and root rots were evident only in storage and not prior to placement in the storage pile.

Frozen root area. Data between experiments for frozen root area were analyzed separately because experiments differed on both the December and January sampling dates $(P=0.0082$ and 0.0100 , respectively). On the 9 December 2005 sampling, four of the six cultivars from the rhizomania-infested field had more frozen root area than those from the noninfested field (Table 4). On the 12 December 2006 sampling, all cultivars from the rhizoma- nia-infested field had more frozen root area than from the noninfested field, except for Owyhee (Table 5). Data collected in January both years did not differ between treatments. Based on contrasts, the two December samplings $(P<0.0001$ for 2005 and 2006) had more frozen root area on roots from the infested field (25 and $41 \%$, respectively) than the noninfested field ( 1 and $2 \%$, respectively). A similar trend was evident in January $2006(P=$ $0.0247)$ but not in January $2007(P=$ 0.3443 ) based on contrasts.

Root weight reduction. Data between storage seasons for root weight reduction were analyzed separately because experiments were different on all sampling dates $(P=0.0014,0.0050,0.0001$, and 0.0003, respectively). In the first experiment, there were some minor differences in weight

Table 3. Percentage of root surface exhibiting rot on sugar beet roots harvested in October 2006 from disease-free and rhizomania-infested trials after storage in an outdoor commercial pile in Twin Falls, ID

\begin{tabular}{llcccc}
\hline & & \multicolumn{4}{c}{ Surface rot (\%) } \\
\cline { 3 - 6 } Cultivar & Virus $^{\mathbf{y}}$ & 1 Nov 2006 & 12 Dec 2006 & 22 Jan 2007 & 26 Feb 2007 \\
\hline HH Meridian R & BNYVV & 0 & $3.4 \mathrm{abc}$ & $25.0 \mathrm{a}$ & $39.5 \mathrm{a}$ \\
HH Acclaim R & BNYVV & 0 & $4.5 \mathrm{a}$ & $20.5 \mathrm{ab}$ & $33.5 \mathrm{ab}$ \\
HM Owyhee & BNYVV & 0 & $4.1 \mathrm{ab}$ & $8.0 \mathrm{c}$ & $30.2 \mathrm{ab}$ \\
Beta 4490 R & BNYVV & 0 & $2.2 \mathrm{abcde}$ & $10.5 \mathrm{bc}$ & $27.0 \mathrm{abc}$ \\
Beta 4199 R & BNYVV & 0 & $2.1 \mathrm{bcde}$ & $10.0 \mathrm{bc}$ & $26.2 \mathrm{abc}$ \\
HM 2984 RZ & BNYVV & 0 & $4.0 \mathrm{ab}$ & $9.5 \mathrm{c}$ & $25.0 \mathrm{bc}$ \\
HM 2984 RZ & None & 0 & $1.2 \mathrm{cde}$ & $7.2 \mathrm{c}$ & $14.2 \mathrm{~cd}$ \\
Beta 4490 R & None & 0 & $0.3 \mathrm{e}$ & $3.0 \mathrm{c}$ & $8.2 \mathrm{~d}$ \\
HH Acclaim R & None & 0 & $3.0 \mathrm{abcd}$ & $11.2 \mathrm{bc}$ & $7.2 \mathrm{~d}$ \\
HH Meridian R & None & 0 & $1.5 \mathrm{cde}$ & $7.2 \mathrm{c}$ & $7.2 \mathrm{~d}$ \\
Beta 4199 R & None & 0 & $0.8 \mathrm{de}$ & $1.4 \mathrm{c}$ & $7.2 \mathrm{~d}$ \\
HM Owyhee & None & 0 & $1.0 \mathrm{de}$ & $2.8 \mathrm{c}$ & $7.0 \mathrm{~d}$ \\
$P>F^{\mathbf{z}}$ & $\ldots$ & N/A & 0.0052 & 0.0025 & $<0.0001$ \\
LSD $(P \leq 0.05)$ & $\ldots$ & $\ldots$ & 2.3 & 10.7 & 13.8 \\
\hline
\end{tabular}

${ }^{\mathrm{x}}$ Surface rot $=$ percentage of root area covered with fungal growth or rotted tissue. Sugar beet roots were harvested 6 to 12 October 2006.

${ }^{\mathrm{y}} \mathrm{BNYVV}=$ Beet necrotic yellow vein virus.

${ }^{\text {z }} P>F$ was the probability associated with the $F$ value; N/A = not applicable. LSD = Fisher's protected least significant difference value.

Table 4. Percentage of frozen root tissue in sugar beet roots harvested in October 2005 from diseasefree and rhizomania cultivar trials that were stored in an outdoor commercial pile in Twin Falls, ID

\begin{tabular}{llccc}
\hline & & \multicolumn{3}{c}{ Frozen root area (\%) $^{\mathbf{x}}$} \\
\cline { 3 - 4 } Cultivar & & \multicolumn{2}{c}{ 9 Dec 2005 } & \\
\cline { 3 - 4 } & Virus $^{\mathbf{y}}$ & Normal & Transformed & 18 Jan 2006 \\
\hline HH Acclaim R & BNYVV & 52 & $7.2 \mathrm{a}$ & 52 \\
HH Meridian R & BNYVV & 26 & $4.3 \mathrm{~b}$ & 45 \\
HM Owyhee & BNYVV & 24 & $4.3 \mathrm{~b}$ & 59 \\
HM 2980 RZ & BNYVV & 22 & $4.2 \mathrm{~b}$ & 49 \\
Beta 4199 R & BNYVV & 16 & $3.1 \mathrm{bc}$ & 24 \\
Beta 4490 R & BNYVV & 8 & $1.9 \mathrm{bc}$ & 39 \\
HH Meridian R & None & 6 & $2.0 \mathrm{bc}$ & 48 \\
HH Acclaim R & None & 1 & $1.0 \mathrm{c}$ & 35 \\
Beta 4490 R & None & 1 & $1.1 \mathrm{c}$ & 28 \\
Beta 4199 R & None & 0 & $0.7 \mathrm{c}$ & 20 \\
HM 2980 RZ & None & 0 & $0.7 \mathrm{c}$ & 21 \\
HM Owyhee & None & 0 & $0.7 \mathrm{c}$ & 32 \\
$P>F^{z}$ & $\ldots$ & $\ldots$ & 0.0006 & 0.3328 \\
LSD $(P \leq 0.05)$ & $\ldots$ & $\ldots$ & 2.9 & NS \\
\hline
\end{tabular}

${ }^{\mathrm{x}}$ Frozen root area $=$ percentage of outside area of the root frozen based on frost or tissues with wet, water-soaked appearance. Sugar beet were harvested and put into storage on 17 October 2005. Transformed $=$ square root transformation to reduce variability and increase normality.

${ }^{\mathrm{y}} \mathrm{BNYVV}=$ Beet necrotic yellow vein virus.

${ }^{\mathrm{z}} P>F$ was the probability associated with the $F$ value. LSD $=$ Fisher's protected least significant difference value. NS $=$ not significantly different. loss depending on sampling date but there were no apparent trends (Table 6). In the second experiment, there were significant differences on all sampling dates (Table 7). On the 1 November 2006 and 12 December 2006 sampling dates, roots of all cultivars from the rhizomania-infested field lost more weight than roots from the noninfested field. Differences between treatments were smaller as time in storage increased. Based on contrasts, the 2005 experiment did not reveal any trends; however, on all sampling dates (October 2006 to February 2007) in the 2006 experiment, roots from the infested field $(10,12,18$, and $17 \%$, respectively) lost more $(P<$ 0.0001 on all dates) weight than those from the noninfested field $(4,6,6$, and $10 \%$, respectively).

Sucrose reduction. On the first sampling date, there were no significant differences between treatments (Tables 8 and 9). On the 9 December 2005 sampling, only the susceptible check, HM Owyhee, showed a significant loss in sugar when comparing roots from the infested and noninfested fields. In the 12 December 2006 sampling, HM Owyhee and HH Acclaim $\mathrm{R}$ both showed a reduction in sucrose when harvested from a rhizomaniainfested field (Table 9). In both January samplings, HM Owyhee and HH Meridian $\mathrm{R}$ from the rhizomania-infested fields both showed a reduction in sucrose. In the 28 February 2006 sampling, five out of the six cultivars grown in the infested field lost substantially more sucrose (43 to $94 \%$ ) than roots from the same cultivars from the noninfested field (15 to 31\%). In the 26 February 2007 sampling, HM Owyhee, $\mathrm{HH}$ Meridian R, and Beta $4490 \mathrm{R}$ all showed a significantly larger reduction in sucrose (19 to $31 \%$ ) than the same cultivars from a noninfested field (8 to $18 \%$ ). The January (2006 and 2007) samples show that storing roots from a rhizomaniainfested field (17.3 and 14.3\%) reduced $(P$ $=0.0035$ and $<0.0001)$ sucrose compared with those from a noninfested field (15.9 and $7.7 \%$ ) based on contrasts. The February (2006 and 2007) samples show that storing roots from a rhizomania-infested field (67.7 and 20.6\%) reduced $(P<$ 0.0001 and 0.0050 ) sucrose compared with those from a noninfested field (20.1 and $13.8 \%$ ) based on contrasts. Contrasts for the 12 December 2006 sampling also showed that sucrose losses $(8.5 \%$ from infested versus $4.6 \%$ noninfested; $P=$ 0.0128 ) due to rhizomania could be documented by early December. Differences among cultivars could not be proven without the influence of rhizomania. However, HH Acclaim R and HH Meridian R ranked the worst both years when averaging the rankings over all samplings without the influence of disease (average ranking in 2005 and 2006): HH Meridian R (1.25 and 2.25), HH Acclaim R (2.25 and 2.75), Beta 4199 R (3.5 and 3.25), HM 2980 RZ (4.25 
and no data), HM 2984 RZ (no data and 3.75), Beta $4490 \mathrm{R}$ (4.25 and 6.0), and HM Owyhee (5.5 and 3.0).

\section{DISCUSSION}

Rhizomania caused by BNYVV had a significant negative impact on the storability of sugar beet based on sucrose loss, susceptibility to freeze damage and rot, and weight loss. The storage losses were evident in not only the rhizomaniasusceptible commercial cv. HW Owyhee but also cultivars considered resistant to BNYVV. Finding that cultivars considered resistant to BNYVV were negatively influenced by this virus problem should not be viewed as completely unexpected because even cultivars with the best resistance are not immune to BNYVV. Because rhizomania is now present in all major production areas, the potential for sugar loss in stored sugar beet roots could easily reach tens of millions in dollars in revenue lost annually. These data highlight the need for further research to develop criteria for the selection of cultivars with good long-term storability and rhizomania resistance, considering storage-related losses as well as performance in the presence of BNYVV infection.

Sucrose loss in sugar beet traditionally has been studied through influences on respiration and storage decay fungi (5). Now the influence of disease problems in the field on the storability of sugar beet is beginning to be studied. In Germany, Rhizoctonia root rot increased storage losses, while Cercospora leaf spot had little influence (12). These data and a lot of previous storage data have been generated under controlled conditions. The rhizomania data presented in this research not only confirm that disease problems in the field can be important in storage but also show that storage problems can be studied under ambient conditions. Work under ambient conditions is likely to be necessary to establish real-world losses; however, to establish criteria for selecting cultivars, work under more controlled conditions may prove to be more beneficial because of reduced environmental influence. The commercial sugar beet piles in the surrounding area also struggled with breakdown problems beginning in midDecember 2005 and early January 2006. In December 2006 and January 2007, with continuous freezing temperatures, the outer portions of the commercial piles froze but were processed in a timely manner. The roots in the storage study responded in a similar manner in both seasons and seemed to be representative of what was occurring in the surrounding area.

The sucrose loss data reported in this study, while quite dramatic, does not include the potential for additional sugar loss in processing. The level of impurities that negatively impact the extraction of sugar in stored roots was not assessed. Previous research showed that roots infested with $R$. solani sustained a reduction in root quality $(3,12)$. Thus, the total loss of sugar in roots infected with BNYVV is likely to be even greater than we report here. Given the loss in sugar established in this report, factories should consider processing roots from fields infested with BNYVV directly and avoid storing roots, if possible.

The impact that ambient temperatures had on these data cannot be ignored, particularly with the impact freeze damage can have on sugar beet. The sugar beet crop grown in 2005 endured a brief but severe cold period (average ambient temperature in pile was -6 to $-8^{\circ} \mathrm{C}$ ) in midDecember followed by 25 days with above-freezing temperatures in January and early February. The 2006 crop dropped

Table 5. Percentage of frozen root tissue in sugar beet roots harvested in October 2006 from diseasefree and rhizomania cultivar trials that were stored in an outdoor commercial pile in Twin Falls, ID

\begin{tabular}{llccc}
\hline & & \multicolumn{3}{c}{ Frozen root area (\%) $^{\mathbf{x}}$} \\
\cline { 3 - 4 } Cultivar & & \multicolumn{2}{c}{ 12 Dec 2006 } & \\
\cline { 3 - 4 } Virus & & Normal & Transformed & 22 Jan 2007 \\
\hline HH Acclaim R & BNYVV & 88 & $9.3 \mathrm{a}$ & 56.2 \\
Beta 4490 R & BNYVV & 60 & $7.8 \mathrm{ab}$ & 71.2 \\
HH Meridian R & BNYVV & 42 & $6.3 \mathrm{bc}$ & 82.5 \\
HM 2984 RZ & BNYVV & 35 & $5.7 \mathrm{c}$ & 68.8 \\
Beta 4199 R & BNYVV & 11 & $3.1 \mathrm{~d}$ & 57.5 \\
HM Owyhee & BNYVV & 10 & $2.5 \mathrm{de}$ & 68.8 \\
HH Meridian R & None & 8 & $2.3 \mathrm{de}$ & 75.0 \\
HH Acclaim R & None & 6 & $2.1 \mathrm{de}$ & 88.8 \\
Beta 4490 R & None & 1 & $1.1 \mathrm{de}$ & 55.0 \\
Beta 4199R & None & 0 & $0.7 \mathrm{e}$ & 53.8 \\
HM 2984 RZ & None & 0 & $0.7 \mathrm{e}$ & 48.8 \\
HM Owyhee & None & 0 & $0.7 \mathrm{e}$ & 25.0 \\
$P>F^{z}$ & $\ldots$ & $\ldots$ & $<0.0001$ & 0.5259 \\
LSD $(P \leq 0.05)$ & $\ldots$ & $\ldots$ & 2.0 & NS
\end{tabular}

${ }^{\mathrm{x}}$ Frozen root area $=$ percentage of outside area of the root frozen based on frost or tissues with wet water soaked appearance. Sugar beet were harvested 6 to 12 October 2006. Transformed $=$ square root transformation to reduce variability and increase normality.

y $\mathrm{BNYVV}=$ Beet necrotic yellow vein virus.

${ }^{\mathrm{z}} P>F$ was the probability associated with the $F$ value. LSD $=$ Fisher's protected least significant difference value. NS = not significantly different.

Table 6. Percent reduction in root weight in sugar beet roots harvested in October 2005 from diseasefree and rhizomania-infested trials and stored in an outdoor commercial pile in Twin Falls, ID

\begin{tabular}{|c|c|c|c|c|c|}
\hline \multirow[b]{2}{*}{ Cultivar } & \multirow[b]{2}{*}{ Virus $^{y}$} & \multicolumn{4}{|c|}{ Reduction in root weight $(\%)^{x}$} \\
\hline & & 31 Oct 2005 & 9 Dec 2005 & 18 Jan 2006 & 28 Feb 2006 \\
\hline HH Acclaim R & BNYVV & $3.4 \mathrm{f}$ & $5.7 \mathrm{~b}$ & 7.1 & 13.8 \\
\hline HH Meridian R & BNYVV & 4.9 bcde & $5.3 \mathrm{~b}$ & 6.8 & 12.0 \\
\hline HM Owyhee & BNYVV & 5.4 abcd & $7.7 \mathrm{a}$ & 7.6 & 11.4 \\
\hline HM 2980 RZ & BNYVV & $4.1 \mathrm{def}$ & $5.6 \mathrm{~b}$ & 5.3 & 9.2 \\
\hline Beta 4490 R & BNYVV & 3.7 ef & $5.1 \mathrm{~b}$ & 6.3 & 8.2 \\
\hline Beta $4199 \mathrm{R}$ & BNYVV & 4.7 cdef & $4.7 \mathrm{~b}$ & 5.2 & 7.8 \\
\hline HH Meridian R & None & $5.3 \mathrm{abcd}$ & $4.8 \mathrm{~b}$ & 7.5 & 13.7 \\
\hline HH Acclaim R & None & $6.1 \mathrm{abc}$ & $5.5 \mathrm{~b}$ & 8.2 & 10.9 \\
\hline Beta $4490 \mathrm{R}$ & None & $6.5 \mathrm{a}$ & $6.4 \mathrm{ab}$ & 8.1 & 10.6 \\
\hline HM Owyhee & None & $5.8 \mathrm{abc}$ & $7.7 \mathrm{a}$ & 7.5 & 9.5 \\
\hline HM 2980 RZ & None & 5.2 abcde & $5.9 \mathrm{~b}$ & 8.1 & 9.4 \\
\hline Beta $4199 \mathrm{R}$ & None & $6.4 \mathrm{ab}$ & $6.1 \mathrm{ab}$ & 6.8 & 7.7 \\
\hline$P>F^{\mathrm{z}}$ & $\ldots$ & 0.0015 & 0.0133 & 0.1561 & 0.3306 \\
\hline $\operatorname{LSD}(P \leq 0.05)$ & $\ldots$ & 1.5 & 1.7 & NS & NS \\
\hline
\end{tabular}

$\mathrm{x}$ Percent reduction in root weight of stored roots in relation to that determined at harvest. Sugar beet were harvested 5 to 7 October 2005.

${ }^{\mathrm{y}} \mathrm{BNYVV}=$ Beet necrotic yellow vein virus

${ }^{\mathrm{z}} P>F$ was the probability associated with the $F$ value. LSD $=$ Fisher's protected least significant difference value. NS = not significantly different. below $0^{\circ} \mathrm{C}$ in late November and stayed sulting in fairly ideal storage conditions. Healthy sugar beet roots continue respirarespiration drops to near zero but does not completely stop until $-18^{\circ} \mathrm{C}$ (24). Howoccurring at -1 to $-3^{\circ} \mathrm{C}(24)$. Considerable time the December sampling was conducted, despite the differences in temperadamage was largely associated with sugar beet that had been produced in BNYVVindicated by the December data from both years; therefore, the temperature at which serious freeze damage occurs should be BNYVV apparently froze more readily, as 
Table 7. Percent reduction in root weight in sugar beet roots harvested in October 2006 from diseasefree and rhizomania-infested trials and stored in an outdoor commercial pile in Twin Falls, ID

\begin{tabular}{|c|c|c|c|c|c|}
\hline \multirow[b]{2}{*}{ Cultivar } & \multirow[b]{2}{*}{ Virus $^{y}$} & \multicolumn{4}{|c|}{ Reduction in root weight $(\%)^{x}$} \\
\hline & & 1 Nov 2006 & 12 Dec 2006 & 22 Jan 2007 & 26 Feb 2007 \\
\hline HM Owyhee & BNYVV & $13.0 \mathrm{a}$ & $14.7 \mathrm{a}$ & $23.2 \mathrm{a}$ & $22.4 \mathrm{a}$ \\
\hline HH Acclaim R & BNYVV & $9.7 \mathrm{bc}$ & $11.5 \mathrm{abc}$ & $14.5 \mathrm{~cd}$ & $18.3 \mathrm{ab}$ \\
\hline HH Meridian R & BNYVV & $9.4 \mathrm{bc}$ & $10.9 \mathrm{bcd}$ & $19.3 \mathrm{ab}$ & $16.8 \mathrm{~b}$ \\
\hline HM 2984 RZ & BNYVV & $11.5 \mathrm{ab}$ & $12.9 \mathrm{ab}$ & $16.8 \mathrm{bc}$ & $16.1 \mathrm{bc}$ \\
\hline Beta 4490 R & BNYVV & $10.6 \mathrm{~b}$ & $12.3 \mathrm{ab}$ & $16.4 \mathrm{bc}$ & $15.4 \mathrm{bc}$ \\
\hline Beta 4199 R & BNYVV & $7.9 \mathrm{~cd}$ & $12.7 \mathrm{ab}$ & $16.9 \mathrm{bc}$ & $15.1 \mathrm{bc}$ \\
\hline HM Owyhee & None & $5.8 \mathrm{de}$ & $6.6 \mathrm{e}$ & $12.0 \mathrm{~d}$ & $12.2 \mathrm{~cd}$ \\
\hline Beta 4199 R & None & $5.3 \mathrm{e}$ & 8.1 cde & $11.9 \mathrm{~d}$ & $12.1 \mathrm{~cd}$ \\
\hline HM 2984 RZ & None & $4.6 \mathrm{e}$ & $6.8 \mathrm{e}$ & $11.6 \mathrm{~d}$ & $12.0 \mathrm{~cd}$ \\
\hline Beta $4490 \mathrm{R}$ & None & $5.3 \mathrm{e}$ & $7.5 \mathrm{de}$ & $14.1 \mathrm{~cd}$ & $11.9 \mathrm{~cd}$ \\
\hline HH Acclaim R & None & $5.7 \mathrm{de}$ & $5.7 \mathrm{e}$ & $11.0 \mathrm{~d}$ & $10.1 \mathrm{~d}$ \\
\hline HH Meridian R & None & $3.7 \mathrm{e}$ & $7.0 \mathrm{e}$ & $12.6 \mathrm{~cd}$ & $9.0 \mathrm{~d}$ \\
\hline$P>F^{\mathrm{Z}}$ & $\ldots$ & $<0.0001$ & $<0.0001$ & $<0.0001$ & $<0.0001$ \\
\hline $\operatorname{LSD}(P \leq 0.05)$ & $\ldots$ & 2.3 & 3.5 & 4.3 & 4.3 \\
\hline
\end{tabular}

${ }^{x}$ Percent reduction in root weight of stored roots in relation to that determined at harvest. Sugar beet were harvested 6 to 12 October 2006.

y $\mathrm{BNYVV}=$ Beet necrotic yellow vein virus.

${ }^{\mathrm{z}} P>F$ was the probability associated with the $F$ value. LSD $=$ Fisher's protected least significant difference value.

Table 8. Percent reduction in sucrose in sugar beet roots harvested from disease-free and rhizomaniainfested trials stored in an outdoor commercial pile in Twin Falls, ID

\begin{tabular}{llcccc}
\hline & & \multicolumn{4}{c}{ Reduction in sucrose $(\%)^{\mathbf{x}}$} \\
\cline { 3 - 6 } Cultivar & Virus $^{\mathbf{y}}$ & $\mathbf{3 1 ~ O c t ~ 2 0 0 5}$ & $\mathbf{9}$ Dec 2005 & 18 Jan 2006 & 28 Feb 2006 \\
\hline HH Meridian R & BNYVV & 6.5 & $13.5 \mathrm{ab}$ & $26.2 \mathrm{a}$ & $94.1 \mathrm{a}$ \\
HH Acclaim R & BNYVV & 6.4 & $11.0 \mathrm{abc}$ & $19.7 \mathrm{ab}$ & $90.9 \mathrm{a}$ \\
HM Owyhee & BNYVV & 7.9 & $17.4 \mathrm{a}$ & $28.8 \mathrm{a}$ & $82.0 \mathrm{a}$ \\
HM 2980 RZ & BNYVV & 2.3 & $8.6 \mathrm{bcd}$ & $8.3 \mathrm{c}$ & $55.1 \mathrm{~b}$ \\
Beta 4199 R & BNYVV & 0.2 & $9.1 \mathrm{bcd}$ & $8.9 \mathrm{c}$ & $42.8 \mathrm{bc}$ \\
Beta 4490 R & BNYVV & 2.0 & $5.0 \mathrm{~cd}$ & $12.0 \mathrm{bc}$ & $41.1 \mathrm{bcd}$ \\
HH Meridian R & None & 11.1 & $14.0 \mathrm{ab}$ & $14.2 \mathrm{bc}$ & $31.2 \mathrm{bcd}$ \\
HH Acclaim R & None & 6.6 & $7.8 \mathrm{bcd}$ & $14.9 \mathrm{bc}$ & $24.4 \mathrm{~cd}$ \\
Beta 4490 R & None & 6.2 & $6.1 \mathrm{~cd}$ & $7.2 \mathrm{c}$ & $18.2 \mathrm{~cd}$ \\
Beta 4199 R & None & 3.7 & $11.5 \mathrm{abc}$ & $12.1 \mathrm{bc}$ & $16.5 \mathrm{~d}$ \\
HM 2980 RZ & None & 5.1 & $11.2 \mathrm{abc}$ & $10.0 \mathrm{c}$ & $15.3 \mathrm{~d}$ \\
HM Owyhee & None & 2.1 & $2.5 \mathrm{~d}$ & $10.8 \mathrm{bc}$ & $15.2 \mathrm{~d}$ \\
$P>F^{z}$ & $\ldots$ & 0.2788 & 7.0121 & 0.0002 & $<0.0001$ \\
LSD $(P \leq 0.05)$ & $\ldots$ & NS & & 9.1 & 26.0 \\
\hline
\end{tabular}

${ }^{x}$ Percent reduction in sucrose of stored roots in relation to that determined at harvest. Sugar beet were harvested 5 to 12 October.

y $\mathrm{BNYVV}=$ Beet necrotic yellow vein virus

${ }^{\mathrm{z}} P>F$ was the probability associated with the $F$ value. LSD $=$ Fisher's protected least significant difference value. NS = not significantly different.

assessed with sugar beet compromised by disease problems in the field. HH Acclaim $\mathrm{R}$, a rhizomania-resistant cultivar, had $88 \%$ of its surface area freeze damaged by 12 December 2006. In fact, roots from most of the rhizomania-resistant cultivars grown in rhizomania-infested fields suffered greater freeze damage than the susceptible check in 2006. Some may argue that this freeze damage is a response to the cultivars' lack of storability and others might argue that it is a reflection of rhizomania resistance. Cvs. $\mathrm{HH}$ Meridian $\mathrm{R}$ and $\mathrm{HH}$ Acclaim $\mathrm{R}$ had better rhizomania resistance ratings than the other resistant cultivars at times based on root observations (Table 1). Yet these two cultivars performed very poorly for most storage variables. In the absence of BNYVV, establishing differences in storability between cultivars was difficult. However, the trends present in the data without disease pressure appear to be amplified in the presence of BNYVV. During the 2006 growing season, the plot areas sampled were not influenced by other major disease problems. During the 2005 growing season, both the infested and noninfested field had exposure to moderate levels of curly top (ameliorated by host resistance and insecticide applications), but the primary difference should have been a response to rhizomania. In addition, $\mathrm{HH}$ Meridian R and $\mathrm{HH}$ Acclaim $\mathrm{R}$ ranked the worst both years for sucrose loss without the influence of rhizomania, indicating that these cultivars potentially have a storability problem. At times, these two cultivars have fewer rhizomania root symptoms than some of the other cultivars; however, the lack of storability potentially offsets this response leading to poor storability. If the research were conducted under more controlled conditions, establishing differences between cultivars with- out BNYVV present might be possible. Nevertheless, conducting this research under ambient conditions was insightful in terms of freeze damage, rot potential, and sugar loss potential.

The considerable root rot found associated with roots from the BNYVV-infested field (72d to $88 \%$ in 2005 and 25 to $40 \%$ in 2006) may be a reflection of the freeze damage endured in December. Although the apparent freeze damage on the 2006 sugar beet was considerably worse than that for 2005, the fluctuations to abovefreezing temperatures in 2005 may explain the increase in rot. Observations in the field would indicate that, once sugar beet roots are frozen, they must remain frozen or be processed within 7 to 10 days or microbial activity will eliminate the possibility of economically extracting sugar (data not shown). If roots are to be stored in a frozen condition, it is important that root temperatures be maintained at less than $-5^{\circ} \mathrm{C}$. Wyse (24) showed that cell damage and loss of sugar occurs at -1 to $-3^{\circ} \mathrm{C}$ and that respiration does not stop until root temperatures reach $-18^{\circ} \mathrm{C}$. Freezing does not impair beet quality as long as they remain frozen; however, roots should be processed immediately upon thawing (12).

In the 2006 roots, BNYVV clearly was associated with a reduction of root mass. In the 2005 roots, a reduction in mass was not established. Perhaps the inoculum levels in the field and ambient temperature differences between years can explain the differential responses. Loss in mass among sugar beet cultivars was 7 to $17 \%$ at $20^{\circ} \mathrm{C}$ in Germany and, when infested with $R$. solani, a $22 \%$ reduction in mass was evident (12).

Cultivars need resistance to storage rot pathogens and a low respiration rate (5). Heritable resistance to storage rot pathogens, as well as other diseases, is present in the sugar beet gene pool $(1,5)$. Germplasm lines bred for resistance to Phoma, Botrytis, and Penicillium spp. have been developed (6). In the past, germplasm lines with low respiration only and lines with low respiration combined with storage rot resistance have been developed and released $(7,8)$. However, this research has been phased out because of the industry's decision to place emphasis on physical methods such as ventilation and freezing to reduce storage losses (5). Sucrose loss in storage occurs because of two general changes: direct loss of sucrose via respiration and loss of sucrose to molasses because of the accumulation of nonsucrose components in the thin juice (25). It could be argued that sucrose losses due to pathogens can rival sucrose lost to respiration. Given the impact that BNYVV has on storability, perhaps there should be a renewed emphasis on storability in sugar beet. Genotypes that improve storability have been established (12) but improving 
Table 9. Percent reduction in sucrose in sugar beet roots harvested from disease-free and rhizomaniainfested trials stored in an outdoor commercial pile in Twin Falls, ID

\begin{tabular}{llcccc}
\hline & & \multicolumn{4}{c}{ Reduction in sucrose (\%) $^{\mathbf{x}}$} \\
Cultivar & Virus $^{\mathbf{y}}$ & 1 Nov 2006 & 12 Dec 2006 & 22 Jan 2007 & 26 Feb 2007 \\
\hline HM Owyhee & BNYVV & 8.0 & $15.1 \mathrm{a}$ & $20.5 \mathrm{a}$ & $31.7 \mathrm{a}$ \\
HH Meridian R & BNYVV & 5.0 & $8.7 \mathrm{abc}$ & $22.2 \mathrm{a}$ & $25.8 \mathrm{ab}$ \\
HH Acclaim R & BNYVV & 10.2 & $14.6 \mathrm{ab}$ & $15.2 \mathrm{ab}$ & $19.7 \mathrm{bc}$ \\
Beta 4490 R & BNYVV & 6.3 & $7.1 \mathrm{bcd}$ & $9.7 \mathrm{bcd}$ & $19.3 \mathrm{bc}$ \\
Beta 4199 R & BNYVV & 7.0 & $5.2 \mathrm{~cd}$ & $8.5 \mathrm{bcd}$ & $14.5 \mathrm{~cd}$ \\
HM 2984 RZ & BNYVV & 0.0 & $0.5 \mathrm{~d}$ & $9.6 \mathrm{bcd}$ & $12.7 \mathrm{~cd}$ \\
HM Owyhee & None & 4.5 & $6.3 \mathrm{~cd}$ & $6.6 \mathrm{~cd}$ & $18.6 \mathrm{bcd}$ \\
Beta 4199 R & None & 2.4 & $4.7 \mathrm{~cd}$ & $8.9 \mathrm{bcd}$ & $14.5 \mathrm{~cd}$ \\
HH Meridian R & None & 6.1 & $7.0 \mathrm{bcd}$ & $7.1 \mathrm{~cd}$ & $14.4 \mathrm{~cd}$ \\
HH Acclaim R & None & 6.1 & $6.2 \mathrm{~cd}$ & $12.4 \mathrm{bc}$ & $14.2 \mathrm{~cd}$ \\
HM 2984 RZ & None & 7.0 & $2.6 \mathrm{~cd}$ & $7.0 \mathrm{~cd}$ & $13.7 \mathrm{~cd}$ \\
Beta 4490 R & None & 0.7 & $0.5 \mathrm{~d}$ & $4.3 \mathrm{~d}$ & $7.6 \mathrm{~d}$ \\
$P>F^{z}$ & $\ldots$ & 0.2046 & 0.0054 & $<0.0001$ & 0.0133 \\
LSD $(P \leq 0.05)$ & $\ldots$ & NS & 7.6 & 7.0 & 11.2 \\
\hline
\end{tabular}

${ }^{x}$ Percent reduction in sucrose of stored roots in relation to that determined at harvest. Sugar beet were harvested 6 to 12 October 2006.

y $\mathrm{BNYVV}=$ Beet necrotic yellow vein virus.

${ }^{\mathrm{z}} P>F$ was the probability associated with the $F$ value. LSD $=$ Fisher's protected least significant difference value. NS = not significantly different.

storability could still be a challenge. Some traits such as respiration and invert sugar accumulation are correlated with sucrose loss but are inherited independently (1). In addition, some traits appear to be governed by both additive and nonadditive gene action. Thus, improving storability in sugar beet will likely be a challenge (1).

Rhizomania negatively impacts harvest yields, having almost eliminated sugar beet production in California before resistant cultivars became available in the 1980 s (19). Resistance-breaking strains of the virus have been identified in major U.S. sugar beet production areas (14). The main control measure for this disease problem is the use of resistant cultivars. However, with the evidence for resistance-breaking strains and additional problems with storage, considerable financial losses due to rhizomania are likely in both the field and storage. Finding new sources of resistance to BNYVV will be important; however, selecting cultivars for varying levels of resistance is difficult in the field. Using the storability of sugar beet roots as a measure for cultivar selection may prove to be important in limiting sugar losses in storage but may enhance recovery of sucrose from fields with a history of BNYVV infection, as well.

\section{ACKNOWLEDGMENTS}

These data support the objectives for the United States Department of Agriculture CRIS project
5368-21220-002-00D. We thank the Amalgamated Sugar Co., Amalgamated Research Inc., Beet Sugar Development Foundation, and Snake River Sugar Beet Growers for supporting our research work; and technical support staff members D. Patterson, P. Foote, J. Smith, M. Funke, D. Kenney, and T. Brown for their efforts.

\section{LITERATURE CITED}

1. Akeson, W. R., and Widner, J. N. 1981. Differences among sugarbeet cultivars in sucrose loss during storage. J. Am. Soc. Sugar Beet Technol. 21:80-91.

2. Bartens, A. 2005. International Commission for Uniform Methods of Sugar Analysis Methods Book 2005. Dr. Albert Bartens KG, Berlin.

3. Bruhns, M., Lemmes, R., and Schick, R., Jr. 2004. Verarbeitungseigenschaften von Rhizoctonia-geschädigten rüben. Zuckerindustrie 129:105-111.

4. Bugbee, W. M. 1982. Storage rot of sugar beet. Plant Dis. 66:871-873.

5. Bugbee, W. M. 1993. Storage. Chapter 14 in: The Sugar Beet Crop: Science into Practice. D. A. Cooke and R. K. Scott, eds. Chapman and Hall, London.

6. Campbell, L. G., and Bugbee, W. M. 1985. Registration of storage rot resistant sugarbeet germplasms F1004, F1005, and F1006. Crop Sci. 25:577.

7. Campbell, L. G., and Bugbee, W. M. 1988. Registration of sugarbeet germplasm with combined storage rot resistance and lowstorage-respiration rate. Crop Sci. 25:577.

8. Campbell, L. G., and Cole, D. F. 1988. Registration of two sugarbeet germplasms having low storage-respiration rates. Crop Sci. 28:205-206.

9. Cole, D. F., and Bugbee, W. M. 1976. Changes in resident bacteria, $\mathrm{pH}$, sucrose, and invert sugar levels in sugarbeet roots during storage. Appl. Environ. Microbiol. 31:754-757.
10. Dexter, S. T., Frakes, M. G., and Nichol, G. 1966. The effect of low, medium and high nitrogen fertilizer rates on the storage of sugar beet roots at high and low temperatures. J. Am. Soc. Sugar Beet Technol. 14:147-159.

11. Kenter, C., and Hoffmann, C. 2005. Lagerung und qualität von zuckerrüben-Welchen einfluss hat die sorte? Zuckerrübe 54:312-316.

12. Kenter, C., Hoffmann, C., and Märländer, B. 2006. Sugarbeet as raw material-advanced storage management to gain good processing quality. Sugar Ind. 131(9):1-15.

13. Klotz, K. L., and Finger, F. L. 2004. Impact of temperature, length of storage, and postharvest disease on sucrose catabolism in sugarbeet. Postharvest Biol. Technol. 34:1-9.

14. Liu, H.-Y., Sears, J. L., and Lewellen, R. T. 2005. Occurrence of resistance-breaking Beet necrotic yellow vein virus of sugar beet. Plant Dis. 89:464-468.

15. Mumford, D. L., and Wyse, R. E. 1976. Effect of fungus infection on respiration and reducing sugar accumulation of sugarbeet roots and use of fungicides to reduce infection. J. Am. Soc. Sugar Beet Technol. 19:157-162.

16. National Agricultural Statistics Service. 2007. Crop production summary for 2006. U. S. Dep. Agric. NASS.

17. Peterson, C. L., Hall, M. C., and Traveller, D. J. 1984. Sugarbeet storage experiments. ASAE Pap. No. 84-4040. ASAE, Knoxville, TN.

18. Rush, C. M. 2003. Ecology and epidemiology of Benyviruses and plasmodiophorid vectors. Annu. Rev. Phytopathol. 41:567-592.

19. Rush, C. M., Liu, H.-Y., Lewellen, R. T., and Acosta-Leal, R. 2006. The continuing saga of rhizomania of sugar beets in the United States. Plant Dis. 90:4-15.

20. SAS Institute, Inc. 1999. The SAS System for Windows. Version 8.2. SAS Institute Inc., Cary, NC.

21. Strausbaugh, C. A., Rearick, E., Camp, S., Gallian, J. J., and Dyer, A. T. 2007. Sugar beet storability and the influence of Beet necrotic yellow vein virus (Abstr.) Phytopathology 97:S111.

22. Ward, L., Koenig, R., Budge, G., Garrido, C., McGrath, C., Stubbley, H., and Boonham, N. 2007. Occurrence of two different types of RNA-5-containing beet necrotic yellow vein virus in the UK. Arch. Virol. 152:59-73.

23. Wisler, G. C., Lewellen, R. T., Sears, J. L., Liu, H.-Y., and Duffus, J. E. 1999. Specificity of TAS-ELISA for beet necrotic yellow vein virus and its application for determining rhizomania resistance in field-grown sugar beets. Plant Dis. 83:864-870.

24. Wyse, R. E. 1978. Effect of low and fluctuating temperatures on the storage life of sugarbeets. J. Am. Soc. Sugar Beet Technol. 20:33-42.

25. Wyse, R. E., and Dexter, S. T. 1971. Source of recoverable sugar losses in several sugarbeet varieties during storage. J. Am. Soc. Sugar Beet Technol. 16:390-398.

26. Wyse, R. E., and Holdredge, R. M. 1982. A comparison of forced ventilation and natural convection as means of cooling sugarbeet storage piles in several geographic locations. J. Am. Soc. Sugar Beet Technol. 21:235-246. 